\title{
Revised protocol of extracorporeal membrane oxygenation (ECMO) therapy in severe ARDS. Recommendations of the Veno-venous ECMO Expert Panel appointed in February 2016 by the national consultant on anesthesiology and intensive care
}

\author{
Romuald Lango ${ }^{1}$, Zbigniew Szkulmowski², Dariusz Maciejewski ${ }^{3}$, Andrzej Sosnowski ${ }^{4}$, Krzysztof Kusza $^{5}$ \\ ${ }^{1}$ Department of Cardioanaesthesiology, Medical University of Gdańsk, Gdańsk, Poland \\ ${ }^{2}$ Department of Anaesthesiology and Intensive Care, Collegium Medicum, Nicolaus Copernicus University \\ in Toruń, Poland \\ ${ }^{3}$ Anaesthaesiology and Intensive Care Unit, Regional (Voivodship) Hospital in Bielsko-Biała, Poland \\ ${ }^{4}$ Department of Cardiac Surgery, Glenfield Hospital, Groby Road, Leicester, United Kingdom (Emeritus) \\ ${ }^{5}$ Chair of Anaesthesiology and Intensive Care, Poznań University of Health Sciences, Poznań, Poland
}

\begin{abstract}
Extracorporeal membrane oxygenation (ECMO), which enables effective blood oxygenation and carbon dioxide removal for several weeks, has become a well established technique for the treatment of severe acute respiratory failure (V-V ECMO, veno-venous ECMO) or circulatory failure (veno-arterial ECMO). Veno-venous ECMO is a life-saving treatment in patients in whom severe acute respiratory distress syndrome (ARDS) makes mechanical ventilation unlikely to provide satisfactory blood oxygenation for preventing further vital organ damage and progression to death. The protocol below refers only to V-V ECMO therapy as a measure to support blood gas exchange by means of an extracorporeal circuit in adult patients with severe ARDS. Veno-venous ECMO does not provide treatment for acutely and severely diseased lungs but it enables the patient to survive the critical phase of severe ARDS until recovery of lung function. In addition to preventing death from hypoxemia, this technique can also prevent further progression of lung damage due to mechanical ventilation. Recent experience in ECMO therapy since the outbreak of an influenza $A\left(H_{1} N_{1}\right)$ pandemic in 2009, along with technical progress and better understanding of the pathophysiology of ventilator-induced lung injury, have contributed to a significant improvement in ECMO treatment outcomes. Postulated factors related to an increased survival include wider use of ECMO during patient transfer and less intensive anticoagulation protocols. The aim of presenting this revised protocol was to improve ECMO treatment outcomes in patients with severe ARDS, to enhance ECMO accessibility for patients who might possibly benefit from this treatment, to reduce the time until institution of ECMO therapy, and to avoid ECMO therapy in futile cases. The authors believe that this protocol, based on recent papers and their own experience, can provide help and advice both for the centers which develop V-V ECMO program, and for doctors who will refer their patients for treatment in an ECMO center.
\end{abstract}

Anaesthesiology Intensive Therapy 2017, vol. 49, no 2, 88-99

Key words: extracorporeal membrane oxygenation, ECMO, ARDS, acute respiratory failure

Extracorporeal membrane oxygenation (ECMO) is a technique involving blood oxygenation and carbon dioxide removal using an oxygenator and extracorporeal circulation. With modification of an extracorporeal circuit used for cardiac surgery, it can be used to generate blood flow and allow gas exchange for up to several weeks. ECMO may be veno-venous, when blood is drained from the inferior and/or superior vena cava and returned also to a vena cava or the 
right atrium, or veno-arterial, when blood is drained from the inferior vena cava, superior vena cava or the right atrium and returned to large artery.

Veno-venous ECMO (V-VECMO) is used in conditions associated with potentially reversible severe lung dysfunction to a degree that precludes effective gas exchange by mechanical ventilation, while veno-arterial ECMO (V-A ECMO) is used in case of potentially reversible or irreversible heart failure. In the latter situation, V-A ECMO may be used as a bridge to cardiac transplantation or long-term mechanical cardiac support. The present guidelines refer only to V-V ECMO as a method to replace lung function using an extracorporeal circuit in adult patients with severe respiratory failure.

ECMO does not treat lungs but only allows the patient to survive the period of severe lung dysfunction to a degree that precludes effective arterial blood oxygenation and/or carbon dioxide elimination by mechanical ventilation. In addition, V-V ECMO reduces or eliminates the risk of ventilation-related lung damage in patients with severe acute respiratory distress syndrome (ARDS). New-generation ECMO systems provide oxygen at a rate of up to $3 \mathrm{~mL} \mathrm{~kg}^{-1}$ $\mathrm{min}^{-1}$ and eliminate carbon dioxide at a rate of 3-6 $\mathrm{mL} \mathrm{kg}^{-1}$ $\mathrm{min}^{-1}$, which may fully cover the metabolic needs of the patient [1].

Experience with the use of V-V ECMO for the treatment of severe respiratory failure in adults in the recent years, including largely increased use of this technique during an influenza $A\left(\mathrm{H}_{1} \mathrm{~N}_{1}\right)$ pandemic in 2009, along with better understanding of the pathophysiology of ventilator induced lung injury (VILI), contributed to a significant improvement in ECMO treatment outcomes [2]. Safe use of an extracorporeal circuit for a longer time has become possible with advances in ECMO technology including use of centrifugal pumps, polymethylpentene oxygenators, and heparin-coated cannulas. Wider use of ECMO during patient transfer and less intensive anticoagulation during this therapy also contributed to reduced complication rates and better treatment outcomes. ECMO is increasingly used in the treatment of life-threatening asthma, and as bridge therapy to lung transplantation [3]. The role of ECMO for the reduction of VILI was highlighted during the Berlin ARDS conference [4]. In these settings, a modification known as partial ECMO assistance is used, with blood flow reduced to values that allow ventilation in accordance with the criteria of lung protective strategy [3].

The goal of the present update of the guidelines on the use of V-V ECMO is to improve treatment outcomes in patients with severe respiratory failure, increase access to ECMO in those patients in whom this therapy is indicated, reduce the duration of mechanical ventilation that induces further lung damage, and define more clearly those patient groups in whom ECMO therapy does not increase the likeli- hood of recovery. The present guidelines have been developed based on a review of current literature and national experience with the use of V-V ECMO in expert units in Poland. Due to the fact that use of V-V ECMO for the treatment of respiratory failure is a relatively new area of intensive care, subject to further rapid advances, these guidelines should not be treated as definitive, particularly in centers having most expertise with the use of this method.

Clinical studies indicate that ECMO is a relatively safe therapeutic technique which improves outcomes in patients with severe ARDS but is also associated with a risk of serious complications. Thus, ECMO therapy must be undertaken in accordance with specific management principles and algorithms. In the recent years, a number of centers in Poland have been selected that offer adequate organization of care, staff, and equipment to provide ECMO in the treatment of severe respiratory failure. The list of these centers is included in the Appendix 1.

Observational studies suggest improved treatment outcomes if EMCO is initiated in a referring unit and used during patient transport to a specialized tertiary care unit [5]. It the tertiary care unit is equipped with a portable ECMO system, initiation of this therapy in the referring unit by a team from the tertiary care unit should be considered. For this reason, it is desirable to equip ECMO-capable tertiary care units with portable ECMO systems. The basis of appropriate patient selection for ECMO therapy is ineffectiveness of previous guideline-directed conventional therapy.

\section{OUTCOMES OF VENO-VENOUS ECMO}

Most studies published prior to 2009 indicated that survival in patients with severe and critical hypoxemia in ARDS was comparable in patients treated with ECMO or conventional lung ventilation techniques $[6,7]$. The randomized CESAR study that included 180 patients showed somewhat better survival in severe ARDS in patients treated with ECMO compared to conventional treatment [8]. Studies indicate that particularly in severe ARDS complicating influenza, survival with ECMO treatment is higher compared to conventional mechanical lung ventilation. Multiple studies indicate that benefits of ECMO may also be seen in severe ARDS due to other causes but treatment outcomes may be worse compared to severe ARDS secondary to a viral infection.

ECMO is an invasive medical technology which is not free from severe and life-threatening complication, and thus this treatment should be initiated only if reliably defined criteria are met.

\section{TREATMENT OPTIMIZATION BEFORE PATIENT REFERRAL FOR ECMO}

1. Exclusion or elimination of potentially reversible causes of worsening of lung function and ventilation param- 
eters, including pneumothorax, significant pleural effusion, bronchial obstruction with mucus or clots, pulmonary congestion, and increased extravascular lung water volume.

2. Ventilation according to the lung protective strategy: tidal volume $\left(\mathrm{V}_{\mathrm{T}}\right) \leq 6 \mathrm{~mL} \mathrm{~kg}^{-1}$ for predicted body weight using the ARDSNet calculator, aiming for $\mathrm{P}_{\text {plateau }}<30 \mathrm{~cm}$ $\mathrm{H}_{2} \mathrm{O}$, permissive hypercapnia, if $\mathrm{P}_{\text {plateau }}>30$ (max. 35) $\mathrm{cm} \mathrm{H}_{2} \mathrm{O}$, recommended ventilation modes include pressure-controlled ventilation (PCV), bilevel positive airway pressure (BIPAP), and BiLevel [9].

3. Adequate sedation. If low volume ventilation is not tolerated and ventilator-patient synchronization is difficult, only in severe ARDS $\left(\mathrm{PaO}_{2} / \mathrm{FiO}_{2}<120\right.$, where $\mathrm{PaO}_{2}$ is partial arterial oxygen pressure and $\mathrm{FiO}_{2}$ is oxygen concentration in inspired air) it is possible to initiate neuromuscular blockade (the preferred drug is cisatracurium) with boluses/continuous intravenous infusion for up to 48 hours [10].

4. Titration of positive end-expiratory pressure (PEEP) to optimal $\mathrm{PaO}_{2} / \mathrm{FlO}_{2}$, lung compliance with consideration of the effect on hemodynamic parameters in the range of 5-15-20 $\mathrm{cm} \mathrm{H}_{2} \mathrm{O}$, optimally in the range defined by the derecruitment technique.

5. Performing lung recruitment maneuvers (LRM) every 4-8 hours and after each lung derecruitment. Derecruitment occurs already after 1.5-2.0 seconds following a loss of PEEP in the airways. i.e., after each mucus suctioning from the airways or short-term disconnection of the ventilator circuit. The potential of recruitment may be evaluated using electrical impedance tomography or lung ultrasonography. The following LRM techniques are possible:

a) $P E E P 30 \mathrm{~cm} \mathrm{H}_{2} \mathrm{O}$ for 20 seconds, peak pressure up to $40 \mathrm{~cm}$ $\mathrm{H}_{2} \mathrm{O}$; (it is important to maintain respiratory drive at $<15 \mathrm{~cm} \mathrm{H}_{2} \mathrm{O}$ )

b) performing two inspirations prolonged to 20 seconds, with the peak pressure of $40 \mathrm{~cm} \mathrm{H}_{2} \mathrm{O}$ - may be achieved by pressing the "respiratory pause" key in some ventilator types. Blood pressure and oxygen saturation must be monitored during LRM.

c) derecruitment technique - LRM combined with determination of optimal PEEP value:

- BIPAP ventilation;

- reduction of pressure support (PS) to $0 \mathrm{~cm} \mathrm{H}_{2} \mathrm{O}$;

- change of inspiratory positive airway pressure (IPAP) to achieve tidal volume of $6 \mathrm{~mL} \mathrm{~kg}^{-1}$;

- determination of the IPAP-EPAP (expiratory positive airway pressure) (or IPAP-PEEP) difference needed to maintain the tidal volume of $6 \mathrm{~mL} \mathrm{~kg}^{-1}$;

- increasing inspiratory pressure by 3-4 steps of 5-7 cm $\mathrm{H}_{2} \mathrm{O}$ to IPAP of $40-45 \mathrm{~cm} \mathrm{H}_{2} \mathrm{O}$, maintaining a constant
IPAP-EPAP difference determined previously. Duration of ventilation at each pressure level during subsequent steps - 3-4 breathing cycles;

- if the ventilator cannot change both IPAP and EPAP at the same time, EPAP is increased first, followed by IPAP (to avoid a temporary increase in the tidal volume above $6 \mathrm{~mL} \mathrm{~kg}^{-1}$ ). The highest pressure level should be maintained for about 3 breathing cycles, with careful monitoring of hemodynamic parameters and reduction of inspiratory pressures in case of instability (hypotension, heart rate changes);

- gradual reduction of inspiratory pressures while maintaining a constant IPAP-EPAP difference, every 3-4 breathing cycles in steps of 4-5 $\mathrm{cm} \mathrm{H}_{2} \mathrm{O}$ initially (down to EPAP of about $25 \mathrm{~cm} \mathrm{H}_{2} \mathrm{O}$ ) followed by $2 \mathrm{~cm} \mathrm{H}_{2} \mathrm{O}$, while monitoring the tidal volume;

- if the ventilator cannot change both IPAP and EPAP at the same time, IPAP is decreased first followed by EPAP (to avoid a temporary increase in the tidal volume above $\left.6 \mathrm{~mL} \mathrm{~kg}^{-1}\right)$;

- tidal volume should be monitored during each step/at each pressure level;

- during reduction of inspiratory pressures, the tidal volume increases (due to increasing lung compliance) or is kept at the same level until EPAP is reduced below the lower inflection point on the pressure-volume curve (the point when alveolar derecruitment begins);

- optimal EPAP is $2 \mathrm{~cm} \mathrm{H}_{2} \mathrm{O}$ below the derecruitment point determined as above;

- as reduction of airway pressure below the derecruitment point resulted in alveolar collapse, repeating the recruitment maneuver described above is needed to reopen the alveoli;

- during the latter step, inspiratory pressure may be reduced at a faster rate.

- when EPAP of $2 \mathrm{~cm} \mathrm{H}_{2} \mathrm{O}$ above the determined derecruitment point is achieved, IPAP is adjusted to achieve the tidal volume of about $6 \mathrm{~mL} \mathrm{~kg}^{-1}$.

6. While determining PEEP, use of the stress index may be helpful. Determination of the latter is based on visual representation of the pressure-volume curve during volume controlled ventilation (VCV). Optimal PEEP is associated with a linear pressure-volume curve in its middle segment, also indicating normal elastance $[11,12]$.

7. Compliance of the respiratory system $\left(C_{R S}\right)$ is related to the air-filled lung volume. Thus, optimal ventilation should be associated with the driving pressure $(\Delta \mathrm{P})$ of $<7 \mathrm{~cm} \mathrm{H}_{2} \mathrm{O}$, where $\Delta \mathrm{P}=\mathrm{V}_{\mathrm{T}} / \mathrm{C}_{\mathrm{RS}}\left(\mathrm{C}_{\mathrm{RS}}\right.$ - static compliance) $(\triangle \mathrm{P}=$ pleural pressure $[\mathrm{Ppl}]-\mathrm{PEEP})$. A strong correlation is found between the driving pressure and energytrauma and development of VILI [13]. 
8. Careful and frequent airway toilet (using bronchofiberscope if possible). LRM should be performed after each airway cleaning procedure.

9. Careful consideration of steroid therapy: methyloprednisolone $0.5-2.5 \mathrm{mg} \mathrm{kg}^{-1}$ day $^{-1}$ for 7 days is particularly indicated if lung histology (by transbronchial or fineneedle biopsy) shows evidence of fibrosis.

10. Use of optimal fluid therapy, defined as avoiding volume overload and maintaining a negative fluid balance if possible, using continuous renal replacement therapy techniques if needed. If extravascular lung water (EVLW) volume may be measured, attempts should be made to reduce it below $10 \mathrm{~mL} \mathrm{~kg}^{-1}$.

11. Aiming to optimize the cardiovascular status based on invasive hemodynamic monitoring in case of hemodynamic instability (techniques that allow EVLW monitoring by transpulmonary termodilution are preferred).

12. If ventilation in the prone position is associated with a significant improvement of the $\mathrm{PaO}_{2} / \mathrm{FIO}_{2}$ ratio, the patient should be placed in the prone position for 6 to 8 hours at least twice during 24 hours. During ventilation in the prone position, recruitment maneuvers should be performed and optimal PEEP value should be determined by the derecruitment approach described above.

13. Evaluation of the effectiveness of advanced ventilation techniques (depending on the capabilities and experience of the unit) including pressure-limited ventilation, inverse ratio ventilation (IRV), airway pressure release ventilation (APRV), oscillatory ventilation, independent lung ventilation, and determination of optimal PEEP by esophageal pressure measurement.

14. If available, an attempt may be made to optimize oxygenation using inhaled nitric oxide (NO) or nebulized prostacyclin analog (iloprost). One management algorithm is to administer NO at 10 ppm for 30 minutes. This therapy should be continued if it is associated with a significant increase in $\mathrm{PaO}_{2}$, and if not - administration of NO should be discontinued [14].

15. Use of techniques to reduce ventilator-associated pneumonia (VAP) including rational antibiotic therapy, avoiding reintubation, tracheal intubation and insertion of an orogastric tube, patient positioning at $30-45^{\circ}$, subglottic suctioning, monitoring sedation intensity (e.g., using Richmond Agitation-Sedation Scale or Riker Agitation-Sedation Scale) [15-17], initiation of enteral feeding within 72 hours of treatment, blood glucose level monitoring, and prevention of peptic ulcer disease and deep venous thrombosis.

16. It should be clearly stressed that the selected mode of ventilation should also be used during patient transport for diagnostics and surgical procedures, and to other units. This is possible using an appropriate quality transport ventilator with adequate oxygen supply.

Before transporting the patient, it is reasonable to ventilate the patient in the intensive care unit with the transport ventilator and evaluate the effectiveness of ventilation.

\section{MONITORING AND LABORATORY TESTS BEFORE PATIENT REFERRAL FOR ECMO}

Basic:

- pulse oximetry,

- arterial blood gases - not less than every 3 hours,

- direct blood pressure measurement,

- central venous pressure measurement,

- renal function parameters,

- myocardial necrosis biomarkers,

- ventilation parameters including tidal volume, breathing rate, $\mathrm{FIO}_{2}$, peak inspiratory pressure (PIP), static lung compliance, and PEEP — recorded not less than every hour,

- chest X-ray,

- pleural ultrasound,

- chest computed tomography should be considered the preferred modality for imaging the lungs,

- blood lactate level.

Additional (if available in a given unit):

- echocardiography,

- if influenza $A\left(\mathrm{H}_{1} \mathrm{~N}_{1}\right)$ virus infection is suspected, it is indicated to confirm this etiology by polymerase chain reaction (PCR).

\section{MEDICAL INDICATIONS FOR TREATING ACUTE RESPIRATORY FAILURE WITH ECMO}

The indication for V-V ECMO is respiratory failure with hypoxemia and hypercapnia persisting despite use of large oxygen concentrations, advanced ventilator techniques and optimization of the patient's condition, which is associated with a risk of further worsening of the patient's condition, ultimately leading to death.

When evaluating the need for patient referral for ECMO, changes in gas exchange parameters following use of advanced ventilator techniques and optimization of the patient's condition should be taken into account, but it should also be remembered that delaying initiation of ECMO reduces the chance of survival.

Basic criterion:

Severe ARDS by the Berlin criteria [4] and at least one of the following criteria:

- $\mathrm{PaO}_{2} / \mathrm{FlO}_{2}<80$ for $\geq 3$ hours despite $\mathrm{V}_{\mathrm{T}}$ of $6 \mathrm{~mL} \mathrm{~kg}^{-1}$ and PEEP of $\geq 5 \mathrm{~cm} \mathrm{H}_{2} \mathrm{O}$ and performance of LRM as described above;

- $\mathrm{pH}<7.25$ for $\geq 3$ hours. 
Additional criteria:

- $\mathrm{pH}<7.2, \mathrm{PaCO}_{2}>80 \mathrm{~mm} \mathrm{Hg}$,

- static lung compliance $<0.5 \mathrm{~mL} \mathrm{~cm} \mathrm{H}_{2} \mathrm{O}^{-1}$,

- PIP $>40 \mathrm{~cm} \mathrm{H}_{2} \mathrm{O}$ with $\mathrm{V}_{\mathrm{T}} \leq 6 \mathrm{~mL} \mathrm{~kg}^{-1}$,

- oxygenation index $\mathrm{Ol}=\left(\mathrm{MAP} \times \mathrm{FIO}_{2} \times 100\right) / \mathrm{PaO}_{2}>$ $60 \mathrm{~mm} \mathrm{Hg}$ for 30 minutes or $>35 \mathrm{~mm} \mathrm{Hg}$ for 6 hours (MAP - mean airway pressure);

- chest X-ray showing extensive consolidations in at least two lung quadrants or alternatively:

- Murray lung injury score (LIS, Lung Injury Score) [18] > 3.0;

— severity of the patient's condition should be evaluated twice daily using the Sequential Organ Failure Assessment (SOFA) score. However, the SOFA score does not serve as an inclusion or exclusion criterion for ECMO.

It should be noted that the simplified definition of ARDS (Kigali modification) is used for screening purposes only and should not be used for patient selection for ECMO [19].

\section{PARAMETERS OF MAJOR IMPORTANCE FOR PREDICTING THE NEED FOR ECMO}

It has been found that outcomes of ECMO are best when this therapy is initiated as soon as possible after respiratory failure develops. Thus, early identification of patients likely to need ECMO is of major importance, so as to refer these patients promptly to the nearest center offering ECMO therapy [20].

\section{OXYGENATION INDEX}

Compared to $\mathrm{PaO}_{2} / \mathrm{FiO}_{2}$, a better prognostic parameter indicating the need for ECMO may be the oxygenation index (OI) (see additional criteria above), defined as the product of the reciprocal of $\mathrm{PaO}_{2} / \mathrm{FiO}_{2}$ and the mean airway pressure (MAP) in $\mathrm{cm} \mathrm{H}_{2} \mathrm{O}$ [20].

$$
\mathrm{OI}=\left(\mathrm{FiO}_{2} \times \mathrm{MAP} \times 100\right) / \mathrm{PaO}_{2}
$$

However, the available data are still inadequate to define specific Ol index that would serve as a criterion to initiate ECMO.

\section{ARDS INDEX}

It has been postulated that an important parameter predicting the need for ECMO may also be the ARDS index after 12 hours of ventilation [20].

ARDS index $=\mathrm{OI} \times\left(\mathrm{MV} \times \mathrm{PaCO}_{2} / 40\right)$

ARDS index $=\left(\mathrm{FiO}_{2} \times \mathrm{MAP} \times \mathrm{MV} \times \mathrm{PaCO}_{2}\right) / \mathrm{PaO}_{2} \times 40$

( $\mathrm{MV}$ - minute ventilation in $\mathrm{L} \mathrm{min}^{-1}$ )

ARDS index above 300 after 12 hours of ventilation is a significant parameter indicating the need for ECMO [20].

\section{CHANGE IN PAO $/ \mathrm{FIO}_{2}$}

It has been observed that a reduction in $\mathrm{PaO}_{2} / \mathrm{FiO}_{2}$ by more than 100 during the first 12 hours of ventilation indicates a significant likelihood of the need for ECMO [20].

\section{ADDITIONAL REMARKS}

In patients with severe lung dysfunction that may soon fulfill the criteria for V-V ECMO, gastric contents aspiration as the cause of impaired gas exchange, body mass index (BMI) $>30 \mathrm{~kg} \mathrm{~m}^{-2}$ and conditions associated with immunosuppression decrease the likelihood of the need for life-saving therapy with ECMO [20].

\section{CONTRAINDICATIONS TO VENO-VENOUS ECMO}

Absolute contraindications:

- previous mechanical ventilation with high peak airway pressure or high oxygen concentration in inspired air for more than 7 days $[5,20]$;

- severe systemic disease with unfavorable prognosis, regardless of the effectiveness of therapy for ARDS;

- severe irreversible central nervous system damage, encephalopathy [5];

- cirrhosis with ascites, history of esophageal variceal bleeding [5];

- malignancy associated with unfavorable prognosis [5];

- chronic respiratory disease associated with unfavorable prognosis;

- intracranial bleeding and other absolute contraindications for anticoagulation;

- Severe chronic pulmonary hypertension (mean pulmonary arterial pressure [mPAP] $>50 \mathrm{~mm} \mathrm{Hg}$ [5];

- severe left ventricular failure (left ventricular ejection fraction $[\mathrm{LVEF}]<25 \%$ ) or right ventricular failure before the occurrence of hypoxemia [5];

- informed patient refusal of ECMO therapy.

Relative contraindications:

- Age $>70$ years [20],

- AIDS [5],

- body mass $>150 \mathrm{~kg}$ [20],

- other factors associated with a significantly reduced likelihood of survival.

\section{MANAGEMENT TEAM}

Therapy with ECMO involves close cooperation between anesthesiology and intensive care specialists, cardiac surgeons, intensive care unit nursing personnel, and perfusionists. This cooperation should be based on the following principles:

1. An anesthesiology and intensive care specialist familiar with the principles and the management of ECMO therapy is present in the unit for 24 hours a day.

2. If possible, a surgeon familiar with the principles and the management of ECMO therapy, including device operation, is at standby for 24 hours (e.g., a physician on duty in a cardiac surgery unit).

3. Direct patient care is provided by intensive care unit nursing personnel familiar with the principles and the 
management of ECMO therapy, including device operation.

4. A perfusionist may be helpful to monitor therapy by checking up the system at least once daily.

\section{ORGANIZATIONAL ISSUES AND ACTIVITIES ASSOCIATED WITH PATIENT REFERRAL FOR ECMO}

After confirming indications and excluding contraindications, the physician referring a patient for ECMO therapy should undertake the following actions after a consultation with a physician in charge of the unit:

1. If possible, explain the nature of and the risk associated with ECMO to the patient or his/her relative, and obtain the patient's consent for this therapy.

2. Liaise with the physician on duty in the nearest or organizationally appropriate unit providing ECMO therapy to verify indications and exclude contraindications, and jointly discuss the appropriateness of therapy in case of doubts. The referring physician is obliged to verify accordance of the previous therapy with the above guidelines, particularly in regard to appropriate ventilator therapy.

3. After the patient is selected for ECMO therapy, it is necessary to establish whether the nearest unit providing ECMO is able to accept the patient and whether an ECMO system is available for the patient in question.

4. If an appropriate hospital bed or an ECMO system is not available, a next nearest unit providing ECMO therapy should be contacted and the points 2 and 3 of the procedure should be repeated.

5. If a destination place for further therapy is agreed, patient transport should be arranged using an appropriate quality transport ventilator. The referring unit is responsible for the organization of patient transport. If a portable ECMO system is available in the accepting unit, it is preferable that a team from the accepting unit comes to the referring unit, initiates V-V ECMO, and transports the patient to the accepting unit $[20,21]$. However, this approach depends on the organizational and staffing capabilities of the unit providing ECMO therapy and cannot be considered obligatory at the present stage.

6. The referring unit is obliged to accept the patient for further treatment after ECMO therapy is discontinued and the patient's cardiovascular status is stabilized to a degree that allows safe transport.

\section{SETTING UP VENO-VENOUS ECMO}

1. Adequate anticoagulation should be instituted before cannulation. The most commonly used approach is to administer unfractionated heparin 5000 units or 100 units $\mathrm{kg}^{-1}$.
2. The device inflow cannula is most commonly inserted to the vena cava inferior through the femoral vein, and the return (outflow) cannula is inserted to the vena cava superior through the internal jugular vein or to the vena cava inferior through the femoral vein. The optimal level for the device inflow cannula insertion may be T10-T11, as deeper insertion may interfere with venous return from the hepatic veins.

3. If inflow through a cannula inserted through the femoral vein is insufficient, an additional cannula may be inserted to the vena cava superior through the internal jugular vein, or to the contralateral femoral vein, depending on the location of the return cannula, and both inflow cannulas are connected with a Y-connector.

4. An alternative approach is insertion of a dedicated ECMO cannula through the interior jugular vein which allows venous inflow to the ECMO device from the inferior and superior venae cavae and blood return to the right atrium at the level of the tricuspid valve.

5. When setting up the extracorporeal circuit, particular care should be paid to careful air removal from the system.

6. Cannulas should be inserted and connected to the extracorporeal ECMO circuit by a cardiac surgeon, vascular surgeon, or adequately trained intensive care unit physician. Aseptic conditions should be maintained and cannulas should be protected from inadvertent disconnection or sliding out.

\section{MANAGEMENT DURING ECMO THERAPY}

1. Normal arterial gas partial pressures are obtained mostly by gas exchange in the ECMO oxygenator. Ventilation is only an additional measure and should be conducted in a way that allows as rapid lung regeneration as possible. Moderate or high PEEP values should be maintained $\left(10-18 \mathrm{~cm} \mathrm{H}_{2} \mathrm{O}\right)$ with low ventilation rate of $12-14 \mathrm{~min}^{-1}$ and maintenance of a pressure-limited ventilation mode [22].

2. Veno-venous ECMO is the major treatment approach in acute respiratory failure with hypoxemia that cannot be corrected using advanced ventilation techniques. If significant circulatory failure coexists, it is mostly due to hypoxemia, and thus cardiovascular function usually improves rapidly once normal blood oxygenation is restored.

3. In special cases, V-A ECMO should be considered (in patients with heart failure due to myocarditis or pericarditis, previous severe cardiovascular disease, or significantly elevated cardiac biomarkers) if cardiac support with large catecholamine doses is needed. Cases of concomitant ARDS and acute heart failure due to viral myocarditis have been reported, e.g. in influenza $\mathrm{A}\left(\mathrm{H}_{1} \mathrm{~N}_{1}\right)$ infection. 
4. Fresh gas flow rates should be adjusted to $\mathrm{PaCO}_{2}$, with flow increase in case of hypercapnia, and flow reduction if $\mathrm{PaCO}_{2}$ is too low.

5. Blood flow rate generated by the centrifugal ECMO pump is adjusted to achieve optimal arterial blood oxygenation (desired $\mathrm{PaO}_{2} 100-150 \mathrm{~mm} \mathrm{Hg}$ ). Initial flow rate is usually set at 3-5 $\mathrm{L} \mathrm{min}^{-1}$. Values recommended by the Extracorporeal Life Support Organization (ELSO) are 60-80 $\mathrm{mL} \mathrm{min}^{-1}$ [23]. Increasing blood flow through the oxygenator increases $\mathrm{PaO}_{2}$, and decreasing blood flow reduces $\mathrm{PaO}_{2}$. Except in patients with ARDS secondary to sepsis, the ratio of ECMO blood flow to cardiac output above $60 \%$ allows adequate arterial blood oxygenation $\left(\mathrm{SaO}_{2}>90 \%\right)$ [24]. If oxygenation cannot be improved to that level (see Table 1), many centers believe that maintaining $\mathrm{SaO}_{2}$ of about $80 \%$ is safe [25]. Observational studies indicate, however, that persistently reduced $\mathrm{PaO}_{2}$ correlates with cognitive dysfunction [25].

6. If achieving minimal oxygenation $\left(\mathrm{PaO}_{2} 70 \mathrm{~mm} \mathrm{Hg}\right)$ is not possible due to inadequate venous inflow, correcting the position of the cannula or insertion of an additional inflow cannula should be considered.

7. During ECMO therapy, lung protective ventilation should be used, with tidal volume $<6 \mathrm{~mL} \mathrm{~kg}^{-1}$, peak inspiratory pressure (PIP) $20-25 \mathrm{~cm} \mathrm{H}_{2} \mathrm{O}$, breathing rate $10 / \mathrm{min}^{-1}$, PEEP $10-15 \mathrm{~cm} \mathrm{H}_{2} \mathrm{O}$, and $\mathrm{FIO}_{2} 0.3$, or ventilator weaning should be aimed for.

8. Use of heparin- or phosphorylcholine-coated systems is beneficial [6].

9. According to the ELSO recommendations, anticoagulation with continuous infusion of unfractionated heparin adjusted to increase the activated clotting time (ACT) to 180-220 seconds or the activated partial thromboplastin time (APTT) to 40-55 seconds is necessary to prevent blood clotting in the extracorporeal circuit during ECMO therapy [23]. In the recent years, a trend to reduce the intensity of anticoagulation has been observed (target ACT 160-200 seconds). Enoxaparin $40 \mathrm{mg}$ daily was also reported to be used to prevent clotting. In an observational study that included 61 patients treated for the overall treatment duration of 56 days, thrombotic complications were observed in 4 patients ( 3 cases of ECMO circuit failure due to circuit clotting, 1 case of myocardial infarction), and bleeding complications occurred in only $18 \%$ of patients [26]. Arguments for reducing the intensity of anticoagulation in patients treated with V-V ECMO seem reasonable but no sufficient evidence from comparative studies are yet available to recommend reduction of anticoagulation to prophylactic low-molecular-weight heparin doses.

10. During ECMO therapy, platelet count should be maintained above $100 \mathrm{G} \mathrm{L}^{-1}$.
11. If possible, invasive procedures should be avoided during ECMO therapy to limit the risk of bleeding complications. Tracheotomy should be considered before initiation of ECMO therapy, or the intensity of anticoagulation should be reduced at the time of tracheotomy $[6,27]$.

12. Hemoglobin level should be kept above $10-12 \mathrm{~g} \mathrm{dL}^{-1}$, depending on the patient's condition. In practice, this may mean that at least 2-3 units of packed red blood cells may need to be transfused daily [28]. This is also associated with a need for transfusion of fresh frozen plasma. According to the ELSO recommendations, maintaining $\mathrm{SaO}_{2}$ not lower than $80 \%$ with hematocrit of $40 \%$ allows adequate oxygen transport [29].

13. If evidence of volume overload is present before or during ECMO therapy, which is often the case, reduction of volume overload should be aimed for but attention should also be paid to maintain appropriate tissue perfusion.

14. Adequate sedation should be continued during the first days of therapy. During subsequent days, attempts should be made to reduce sedation to allow pressure support ventilation (PSV). If allowed by the general condition of the patient, weaning of ventilator therapy, removal of the endotracheal tube and respiratory rehabilitation may be beneficial.

15. All attempts should be made to prevent hypothermia resulting from heat loss by the extracorporeal circuit cannulas.

16. Acute kidney injure is a frequent complication in patients with severe respiratory failure who require therapy with V-V ECMO. The Acute Kidney Injury Network (AKIN) II or III criteria are met in $25-67 \%$ of patients treated with ECMO, and $21-24 \%$ of patients require renal replacement therapy [30]. Available studies do not include a recommendation regarding using the ECMO circuit for renal replacement therapy or performing the latter using a dialysis catheter. The decision regarding the use of the ECMO circuit for renal replacement therapy or using a dialysis catheter should be made based on the experience of the treating unit, characteristics of the renal replacement therapy system in regard to threshold inflow and outflow pressure, and the possibility of inserting a dialysis catheter.

17. The mode of connecting the renal replacement therapy system to the ECMO circuit depends on the relation between pressures in various parts of the ECMO circuit (proximally to the centrifugal pump, between the pump and the oxygenator, and between the oxygenator and the return cannula) and alarm pressures in the inflow and outflow lines in the renal replacement therapy system. In practice, it may be optimal to connect the inflow and outflow lines of the renal replacement therapy system between the centrifugal pump and the oxygenator, or the inflow line between the oxygenator and the return 
cannula and the outflow line between the centrifugal pump and the oxygenator (despite renal replacement therapy system-ECMO circuit recirculation) [31].

\section{MONITORING DURING ECMO THERAPY}

Basic monitoring:

- pulse oximetry,

- arterial blood gases - not less than every 3 hours,

- direct blood pressure measurement,

- measurement of central venous pressure has a minor role, as interpretation of this parameter is limited by active blood suction by the centrifugal pump,

- renal function parameters,

- ventilation parameters including tidal volume, breathing rate, $\mathrm{FIO}_{2}$, PIP, static lung compliance, and PEEP - recorded not less than twice daily,

- blood lactate level,

- ACT or APTT - not less than every 6 hours,

- international normalized ratio (INR), prothrombin time (PTT), D-dimer, fibrinogen, and antithrombin levels, platelet count - daily,

- chest X-ray - not less than every 3 days,

- device function parameters should be recorded every hour, including blood flow rate and pump speed (revolutions per minute). Decreasing blood oxygenation with constant blood flow indicates device "wear" or an increased clotting risk. In such cases, prepare for replacement of the oxygenator or the whole extracorporeal circuit. $\mathrm{PaO}_{2} / \mathrm{FiO}_{2}<200$ in a blood sample taken distally to the oxygenator indicates its "wear" and suggests a possible need for prompt device replacement [26]. A proposed nursing observation chart for ECMO therapy is provided in the Appendix 2.

Additional monitoring (if available in the unit):

- transesophageal echocardiography may be helpful to evaluate valvular function and position of the cannula, particularly with the use of a dual-lumen cannula,

- evaluation of extravascular lung water volume using the Pulse Contour Cardiac Output (PICCO) methods. These parameters must be interpreted with caution due to additional variable blood inflow from the ECMO system to the vena cava superior,

- computed tomography of the chest, abdomen, and head depending on clinical indications,

- bedside lung impedance tomography if available.

\section{TECHNICAL PROBLEMS AND COMPLICATIONS ASSOCIATED WITH ECMO THERAPY}

Patient-related complications:

- bleeding (prevalence approx. 30\%, including cardiac tamponade, hemothorax, gastrointestinal bleeding, bronchial bleeding, central nervous system bleeding, genitourinary bleeding [32]), vessel damage related to cannulation,

- hemolysis,

- thrombocytopenia/heparin induced thrombocytopenia (HIT),

- infection (including respiratory infections, catheterrelated infections, and infections associated with the ECMO cannula ECMO [32]),

- embolic complications,

- neurological complications and long-term cognitive dysfunction,

- organ failure (kidneys, heart, liver),

- lung barotrauma,

- metabolic disturbances,

- right atrial perforation with a cannula.

Complications related to the ECMO device and circuit (prevalence approx. 5\% [3]):

- consequences of incomplete air removal from the circuit,

- air suction to the extracorporeal circuit during therapy,

- cannula dyslocation or sliding out,

- oxygenator dysfunction (wear, thrombosis),

- circuit interruption (disconnection, damage),

- heater-cooler dysfunction,

- pump dysfunction.

Management in case of selected technical problems

Regardless of the mechanism, each device dysfunction leading to reduced blood flow or impaired gas exchange is an immediately life-threatening condition and requires prompt modification of ventilator parameters to allow adequate gas exchange in the lungs. At the same time, a solution of the technical problem should be sought as soon as possible. Most common technical problems and device malfunctions and their suggested management are shown in Table 1.

\section{DISCONTINUATION OF ECMO THERAPY}

- Extensive cerebral ischemia.

- Massive intracranial bleeding.

- On-treatment diagnosis of another progressive condition precluding lung function recovery.

- No recovery of lung function despite prolonged therapy.

- Brain death declared during ECMO therapy.

\section{WEANING FROM ECMO THERAPY}

Prerequisites:

- resolving lung abnormalities on chest X-ray,

- improvement of arterial blood oxygenation at $\mathrm{FIO}_{2}$ $<0.6$ and improvement of lung compliance (PIP $<30$ $\mathrm{Cm} \mathrm{H}_{2} \mathrm{O}$ ) during an attempt to reduce ECMO support. 
Table 1. Most common technical problems and device malfunctions and their suggested management

\begin{tabular}{|c|c|}
\hline Technical problem or device malfunction & Management \\
\hline $\begin{array}{l}\text { Disconnection or leak within the circuit, } \\
\text { cannula sliding out }\end{array}$ & $\begin{array}{l}\text { Immediately clamp the cannulas, call a cardiac surgeon and a perfusionist } \\
\text { Note: To reduce the risk of this problem, check all side ports for closure tightness, protect cannulas } \\
\text { with clamps, and secure them with sutures before initiating ECMO therapy }\end{array}$ \\
\hline $\begin{array}{l}\text { Irregular pump function, reduced blood } \\
\text { flow, temporary reduction of blood flow }\end{array}$ & $\begin{array}{l}\text { Increase intravascular volume, call a cardiac surgeon, correct cannula location, consider inserting an } \\
\text { additional inflow cannula }\end{array}$ \\
\hline Oxygenator thrombosis & Call a cardiac surgeon and a perfusionist. Replace the oxygenator or the whole ECMO system \\
\hline $\begin{array}{l}\text { Presence of thrombi in the volute of the } \\
\text { centrifugal pump or another part of the system }\end{array}$ & Call a cardiac surgeon and a perfusionist. Replace the volute or the whole ECMO system \\
\hline Reduced body temperature & $\begin{array}{l}\text { Call a perfusionist, check functioning of the heater-cooler, provide thermal insulation of the ECMO circuit } \\
\text { Note: Reduction in body temperature as a factor that limits oxygen demand and } \mathrm{CO}_{2} \text { production } \\
\text { may be beneficial and desirable, particularly in case of difficulties with achieving optimal blood flow } \\
\text { during V-A ECMO support }\end{array}$ \\
\hline $\begin{array}{l}\text { Persisting hypoxemia despite ECMO } \\
\text { therapy }\end{array}$ & $\begin{array}{l}\text { An attempt to increase blood flow through the centrifugal pump, increase oxygen concentration } \\
\text { in the ECMO fresh gas supply, adjust position of the cannulas to reduce recirculation, increase } \\
\text { hemoglobin level, institute therapeutic hypothermia, increase sedation and myorelaxation [25] }\end{array}$ \\
\hline
\end{tabular}

ECMO - extracorporeal membrane oxygenation; V-A ECMO — veno-arterial ECMO

\section{ATTEMPT TO REDUCE ECMO SUPPORT TO EVALUATE THE POSSIBILITY OF WEANING FROM ECMO THERAPY}

1. Reduction of $\mathrm{V}-\mathrm{V}$ ECMO support involves termination of fresh gas supply to the oxygenator, usually for at least 2 hours. Reduction of blood flow rate is associated with a risk of thrombosis in the ECMO circuit and is not justified when evaluating respiratory function during weaning from V-V ECMO [26].

2. Maintenance of normal gas exchange parameters during reduction of $V$ - $V$ ECMO support indicates that ECMO therapy may be safely discontinued. In all cases, this decision should be made with adequate caution, taking into account the whole clinical picture.

3. Cannulas may be removed by a cardiac surgeon, vascular surgeon, or an intensive care unit physician. Cannula removal by the latter is considered safe provided that the procedure is adequately prepared and a surgeon is available to intervene in case of complications [33].

\section{ACKNOWLEDGEMENTS}

1. Source of funding: none

2. Conflict of interest: none.

\section{References:}

1. Terragni PP, Birocco A, Faggiano C, et al. Extracorporeal CO2 removal. Contrib Nephrol. 2010; 165: 185-196, doi: 10.1159/000313758, indexed in Pubmed: 20427969.

2. Bastin AJ, Firmin R. Extracorporeal membrane oxygenation for severe acute respiratory failure in adults: NICE guidance. Heart. 2011; 97(20): 1701-1703, doi: 10.1136/heartjnl-2011-300708, indexed in Pubmed: 21859739

3. Terragni P, Faggiano C, Ranieri VM. Extracorporeal membrane oxygenation in adult patients with acute respiratory distress syndrome. Curr Opin Crit Care. 2014; 20(1): 86-91, doi: 10.1097/ MCC.0000000000000053, indexed in Pubmed: 24322337.

4. Ranieri VM, Rubenfeld GD, Thompson BT, et al. ARDS Definition Task Force. Acute respiratory distress syndrome: the Berlin Definition. JAMA. 2012; 307(23): 2526-2533, doi: 10.1001/jama.2012.5669, indexed in Pubmed: 22797452.
5. Forrest $\mathrm{P}$, Ratchford J, Burns $\mathrm{B}$, et al. Retrieval of critically ill adults using extracorporeal membrane oxygenation: an Australian experience. Intensive Care Med. 2011; 37(5): 824-830, doi: 10.1007/s00134-0112158-8, indexed in Pubmed: 21359610.

6. Peek GJ, Moore HM, Moore N, et al. Extracorporeal membrane oxygenation for adult respiratory failure. Chest. 1997; 112(3): 759-764, indexed in Pubmed: 9315812.

7. Zapol WM, Snider MT, Hill JD, et al. Extracorporeal membrane oxygenation in severe acute respiratory failure. A randomized prospective study. JAMA. 1979; 242(20): 2193-2196, indexed in Pubmed: 490805.

8. Peek G, Mugford M, Tiruvoipati R, et al. Efficacy and economic assessment of conventional ventilatory support versus extracorporeal membrane oxygenation for severe adult respiratory failure (CESAR): a multicentre randomised controlled trial. The Lancet. 2009; 374(9698): 1351-1363, doi: 10.1016/s0140-6736(09)61069-2.

9. Burns KEA, Adhikari NKJ, Slutsky AS, et al. Pressure and volume limited ventilation for the ventilatory management of patients with acute lung injury: a systematic review and meta-analysis. PLoS One. 2011; 6(1): e14623, doi: 10.1371/journal.pone.0014623, indexed in Pubmed: 21298026.

10. Papazian L, Forel JM, Gacouin A, et al. ACURASYS Study Investigators. Neuromuscular blockers in early acute respiratory distress syndrome. NEngl J Med. 2010; 363(12): 1107-1116, doi: 10.1056/NEJMoa1005372, indexed in Pubmed: 20843245.

11. Pan C, Tang R, Xie J, et al. Stress index for positive end-expiratory pressure titration in prone position: a piglet study. Acta Anaesthesiol Scand. 2015; 59(9): 1170-1178, doi: 10.1111/aas.12590, indexed in Pubmed: 26198816.

12. Huang $Y$, Yang Yi, Chen $Q$, et al. Pulmonary acute respiratory distress syndrome: positive end-expiratory pressure titration needs stress index. J Surg Res. 2013; 185(1): 347-352, doi: 10.1016/j.jss.2013.05.012, indexed in Pubmed: 23731684.

13. Amato MBP, Meade MO, Slutsky AS, et al. Driving pressure and survival in the acute respiratory distress syndrome. N Engl J Med. 2015; 372(8): 747-755, doi: 10.1056/NEJMsa1410639, indexed in Pubmed: 25693014

14. Gebistorf F, Karam O, Wetterslev J, et al. Inhaled nitric oxide for acute respiratory distress syndrome (ARDS) in children and adults. Cochrane Database Syst Rev. 2016(6): CD002787, doi: 10.1002/14651858. CD002787.pub3, indexed in Pubmed: 27347773.

15. Burry L, Cook D, Herridge M, et al. SLEAP Investigators, Canadian Critical Care Trials Group. Recall of ICU Stay in Patients Managed With a Sedation Protocol or a Sedation Protocol With Daily Interruption. Crit Care Med. 2015; 43(10): 2180-2190, doi: 10.1097/CCM.0000000000001196, indexed in Pubmed: 26181221.

16. Burry L, Rose L, McCullagh IJ, et al. Daily sedation interruption versus no daily sedation interruption for critically ill adult patients requiring invasive mechanical ventilation. Cochrane Database Syst Rev. 2014(7): CD009176, doi: 10.1002/14651858.CD009176.pub2, indexed in Pubmed: 25005604. 
17. Mehta S, Burry L, Cook D, et al. SLEAP Investigators, Canadian Critical Care Trials Group. Daily sedation interruption in mechanically ventilated critically ill patients cared for with a sedation protocol: a randomized controlled trial. JAMA. 2012; 308(19): 1985-1992, indexed in Pubmed: 23180503.

18. Murray JF, Matthay MA, Luce JM, et al. An expanded definition of the adult respiratory distress syndrome. Am Rev Respir Dis. 1988; 138(3): 720-723, doi: 10.1164/ajrccm/138.3.720, indexed in Pubmed: 3202424.

19. Riviello ED, Kiviri W, Twagirumugabe $T$, et al. Hospital Incidence and Outcomes of the Acute Respiratory Distress Syndrome Using the Kigali Modification of the Berlin Definition. Am J Respir Crit Care Med. 2016; 193(1): 52-59, doi: 10.1164/rccm.201503-05840C, indexed in Pubmed: 26352116

20. Bohman JK, Hyder JA, lyer V, et al. Early prediction of extracorporeal membrane oxygenation eligibility for severe acute respiratory distress syndrome in adults. J Crit Care. 2016; 33: 125-131, doi: 10.1016/j. jcrc.2016.01.021, indexed in Pubmed: 26923646.

21. Patroniti N, Zangrillo A, Pappalardo F, et al. The Italian ECMO network experience during the 2009 influenza $A(H 1 N 1)$ pandemic: preparation for severe respiratory emergency outbreaks. Intensive Care Med. 2011; 37(9): 1447-1457, doi: 10.1007/s00134-011-2301-6, indexed in Pubmed: 21732167.

22. Schmidt $M$, Pellegrino V, Combes $A$, et al. Mechanical ventilation during extracorporeal membrane oxygenation. Crit Care. 2014; 18(1): 203, doi: 10.1186/cc13702, indexed in Pubmed: 24447458.

23. Annich G, Lynch W, MacLaren G, Wilson J, Bartlett RE. Extracorporeal cardiopulmonary support in critical care (The "Red Book"). ELSO 4th Edition, Ann Arbor 2013.

24. Schmidt M, Tachon G, Devilliers $C$, et al. Blood oxygenation and decarboxylation determinants during venovenous ECMO for respiratory failure in adults. Intensive Care Med. 2013; 39(5):838-846, doi: 10.1007/ s00134-012-2785-8, indexed in Pubmed: 23291732.

25. Montisci A, Maj G, Zangrillo A, et al. Management of refractory hypoxemia during venovenous extracorporeal membrane oxygenation for ARDS. ASAIO J. 2015; 61(3): 227-236, doi: 10.1097/ MAT.0000000000000207, indexed in Pubmed: 25923575.

26. Krueger K, Schmutz A, Zieger B, et al. Venovenous Extracorporeal Membrane Oxygenation With Prophylactic Subcutaneous Anticoagulation Only: An Observational Study in More Than 60 Patients. Artif Organs. 2017; 41(2): 186-192, doi: 10.1111/aor.12737, indexed in Pubmed: 27256966.
27. Lindén $\mathrm{V}$, Palmér $\mathrm{K}$, Reinhard J, et al. High survival in adult patients with acute respiratory distress syndrome treated by extracorporeal membrane oxygenation, minimal sedation, and pressure supported ventilation. Intensive Care Med. 2000; 26(11): 1630-1637, indexed in Pubmed: 11193269.

28. Esper SA, Levy JH, Waters $\mathrm{JH}$, et al. Extracorporeal membrane oxygenation in the adult: a review of anticoagulation monitoring and transfusion. Anesth Analg. 2014; 118(4): 731-743, doi: 10.1213/ ANE.0000000000000115, indexed in Pubmed: 24651227.

29. Nin N, Lorente JA, Soto L, et al. Acute kidney injury in critically ill patients with 2009 influenza A (H1N1) viral pneumonia: an observational study. Intensive Care Med. 2011; 37(5): 768-774, doi: 10.1007/s00134-0112167-7, indexed in Pubmed: 21394630.

30. Davies A, Jones D, Bailey $M$, et al. Australia and New Zealand Extracorporeal Membrane Oxygenation (ANZ ECMO) Influenza Investigators. Extracorporeal Membrane Oxygenation for 2009 Influenza A(H1N1) Acute Respiratory Distress Syndrome. JAMA. 2009; 302(17): 1888-1895, doi: 10.1001/jama.2009.1535, indexed in Pubmed: 19822628

31. Seczyńska B, Królikowski W, Nowak I, et al. Continuous renal replacement therapy during extracorporeal membrane oxygenation in patients treated in medical intensive care unit: technical considerations. Ther Apher Dial. 2014; 18(6): 523-534, doi: 10.1111/1744-9987.12188, indexed in Pubmed: 25195931.

32. Noah MA, Peek GJ, Finney SJ, et al. Referral to an extracorporeal membrane oxygenation center and mortality among patients with severe 2009 influenza A(H1N1). JAMA. 2011; 306(15): 1659-1668, doi: 10.1001/ jama.2011.1471, indexed in Pubmed: 21976615.

33. Heller A, Dollerschell J, Burk J, et al. Safety of intensivist-led bedside decannulation of internal jugular bi-caval dual-lumen veno-venous extracorporeal membrane oxygenation cannulas and report of technique. Anaesthesiol Intensive Ther. 2016; 48(4): 211-214, doi: 10.5603/ AIT.a2016.0040, indexed in Pubmed: 27689428.

\section{Corresponding author:}

Prof. Romuald Lango, MD, PhD

Department of Cardioanaesthesiology, Medical University of Gdańsk ul. Dębinki 7, 80-211, Gdańsk, Poland

e-mail: rlango@gumed.edu.pl 


\section{Appendix 1}

Centers providing ECMO therapy for the management of severe respiratory failure in Poland as of February 2017

\begin{tabular}{|c|c|c|c|}
\hline Hospital & Unit & Address & $\begin{array}{l}\text { Contact phone } \\
\text { number (prefix }+48 \text { ) }\end{array}$ \\
\hline Śląskie Centrum Chorób Serca w Zabrzu & $\begin{array}{l}\text { Oddział Kliniczny Kardioanestezji } \\
\text { i Intensywnej Terapii }\end{array}$ & Curie-Skłodowskiej 9, 41-800 Zabrze & $\begin{array}{l}322712731 \\
323733800\end{array}$ \\
\hline $\begin{array}{l}\text { Krakowski Szpital Specjalistyczny im. } \\
\text { Jana Pawła II }\end{array}$ & $\begin{array}{l}\text { Oddział Anestezjologii i Intensywnej } \\
\text { Terapii }\end{array}$ & Prądnicka 80, 31-202 Kraków & 126143303 \\
\hline Szpital Uniwersytecki w Krakowie & $\begin{array}{l}\text { Oddział Anestezjologii i Intensywnej } \\
\text { Terapii }\end{array}$ & Skawińska 8, 31-066 Kraków & 124305382 \\
\hline $\begin{array}{l}\text { Uniwersytecki Szpital Kliniczny we } \\
\text { Wrocławiu }\end{array}$ & Klinika Anestezjologii i Intensywnej Terapii & Borowska 213, 50-556 Wrocław & $\begin{array}{l}717332310 \\
717332320 \\
717332311\end{array}$ \\
\hline Szpital Uniwersytecki nr 1 w Bydgoszczy & Klinika Anestezjologii i Intensywnej Terapii & $\begin{array}{l}\text { Skłodowskiej Curie 5, 85-092 } \\
\text { Bydgoszcz }\end{array}$ & $\begin{array}{l}525854022 \\
525854750\end{array}$ \\
\hline $\begin{array}{l}\text { Centralny Szpital Kliniczny Szpital } \\
\text { MSWiA }\end{array}$ & Klinika Anestezjologii i Intensywnej Terapii & Wołoska 137, 02-507 Warszawa & $\begin{array}{l}225081450 \\
225081458\end{array}$ \\
\hline $\begin{array}{l}\text { Uniwersyteckie Centrum Kliniczne } \\
\text { w Gdańsku }\end{array}$ & Klinika Anestezjologii i Intensywnej Terapii & $\begin{array}{l}\text { Smoluchowskiego 17, 80-214 } \\
\text { Gdańsk }\end{array}$ & $\begin{array}{l}583493270 \\
583493295\end{array}$ \\
\hline $\begin{array}{l}\text { Samodzielny Publiczny Szpital Kliniczny } \\
\text { nr } 2\end{array}$ & $\begin{array}{l}\text { Klinika Anestezjologii, Intensywnej Terapii } \\
\text { i Ostrych Zatruć }\end{array}$ & $\begin{array}{l}\text { Powstańców Wielkopolskich 72, } \\
\text { 70-111 Szczecin }\end{array}$ & 914661144 \\
\hline $\begin{array}{l}\text { Uniwersytecki Szpital Kliniczny } \\
\text { w Białymstoku }\end{array}$ & Klinika Anestezjologii i Intensywnej Terapii & $\begin{array}{l}\text { M. Skłodowskiej-Curie } 24 \text { A, 15-278 } \\
\text { Białystok }\end{array}$ & $\begin{array}{l}857468302 \\
857468476\end{array}$ \\
\hline Szpital Wojewódzki w Bielsku-Białej & $\begin{array}{l}\text { Oddział Anestezjologii i Intensywnej } \\
\text { Terapii }\end{array}$ & $\begin{array}{l}\text { Aleja Armii Krajowej 101, 43-300 } \\
\text { Bielsko Biała }\end{array}$ & $338102591-98$ \\
\hline $\begin{array}{l}\text { Samodzielny Publiczny Szpital Kliniczny } \\
\mathrm{Nr} 4\end{array}$ & $\begin{array}{l}\text { I Klinika Anestezjologii i Intensywnej } \\
\text { Terapii }\end{array}$ & Jaczewskiego 8, 20-001 Lublin & $\begin{array}{l}817244332, \\
817244336\end{array}$ \\
\hline Centralny Szpital Kliniczny & Klinika Anestezjologii i Intensywnej Terapii & Pomorska 251, 92-213 Łódź & $\begin{array}{l}422014210 \\
422014216\end{array}$ \\
\hline $\begin{array}{l}\text { Wojewódzki Szpital Specjalistyczny } \\
\text { w Olsztynie }\end{array}$ & $\begin{array}{l}\text { Oddział Kliniczny Anestezjologii } \\
\text { i Intensywnej Terapii }\end{array}$ & Żołnierska 18, 10-561 Olsztyn & $\begin{array}{l}895386243, \\
895386225, \\
895386279\end{array}$ \\
\hline $\begin{array}{l}\text { Szpital Kliniczny Przemienienia } \\
\text { Pańskiego }\end{array}$ & $\begin{array}{l}\text { I Klinika Anestezjologii i Intensywnej } \\
\text { Terapii }\end{array}$ & Długa 1/2, 61-848 Poznań & 618549269 \\
\hline $\begin{array}{l}\text { Kliniczny Szpital Wojewódzki nr } 2 \text { im. } \\
\text { Św. Jadwigi }\end{array}$ & $\begin{array}{l}\text { Klinika Intensywnej Terapii i Anestezjologii } \\
\text { z Ośrodkiem Ostrych Zatruć }\end{array}$ & Lwowska 60, 35-301 Rzeszów & $\begin{array}{l}178664859 \\
178664860\end{array}$ \\
\hline \multicolumn{4}{|c|}{ Centers providing ECMO therapy in pediatric patients } \\
\hline Uniwersytecki Szpital Dziecięcy & $\begin{array}{l}\text { Oddział Anestezjologii i Intensywnej } \\
\text { Terapii }\end{array}$ & Wielicka 265, 30-663 Kraków & $\begin{array}{l}126582011 \\
\text { ext. } 1522,1525\end{array}$ \\
\hline Szpital Kliniczny im. Karola Jonschera & $\begin{array}{l}\text { Klinika Anestezjologii i Intensywnej } \\
\text { Terapii Pediatrycznej }\end{array}$ & Szpitalna 27/33, 60-572 Poznań & $\begin{array}{l}618491478, \\
618491438, \\
618491489\end{array}$ \\
\hline $\begin{array}{l}\text { Szpital-Pomnik Centrum Zdrowia } \\
\text { Dziecka }\end{array}$ & $\begin{array}{l}\text { Klinika Anestezjologii i Intensywnej } \\
\text { Terapii }\end{array}$ & $\begin{array}{l}\text { Aleja Dzieci Polskich 20, 04-730 } \\
\text { Warszawa }\end{array}$ & $\begin{array}{l}228151335 \\
228151332\end{array}$ \\
\hline $\begin{array}{l}\text { Uniwersytecki Szpital Kliniczny we } \\
\text { Wrocławiu }\end{array}$ & $\begin{array}{l}\text { Oddział Anestezjologii i Intensywnej } \\
\text { Terapii Dziecięcej }\end{array}$ & Borowska $213,50-556$ Wrocław & $\begin{array}{l}717332310 \\
717332320\end{array}$ \\
\hline
\end{tabular}




\section{Appendix 2}

Nursing observation chart Date:

Patient name:

PESEL number.

\begin{tabular}{|c|c|c|c|c|c|c|c|}
\hline $\begin{array}{l}\text { Hour ( } 24 \text { hour } \\
\text { clock) }\end{array}$ & $\begin{array}{l}\text { ECMO blood } \\
\text { flow }\left[\mathrm{L} \mathrm{min}^{-1}\right]\end{array}$ & $\begin{array}{l}\text { ECMO } \\
\text { pump speed } \\
\text { (revolutions } \\
\text { per minute) } \\
\end{array}$ & $\begin{array}{c}\mathrm{SpO}_{2} \\
\text { (pulse } \\
\text { oximetry) }\end{array}$ & $\begin{array}{l}\text { ECMO gas } \\
\text { supply flow }[\mathrm{L} \\
\left.\text { min }^{-1}\right]\end{array}$ & $\begin{array}{c}\text { Oxygen level } \\
\text { in ECMO gas } \\
\text { supply }\end{array}$ & ACT or APTT & $\begin{array}{l}\text { Remarks/ } \\
\text { problems/ } \\
\text { alarm type }\end{array}$ \\
\hline \multicolumn{8}{|l|}{$7.00-8.00$} \\
\hline \multicolumn{8}{|l|}{$8.00-9.00$} \\
\hline \multicolumn{8}{|l|}{$9.00-10.00$} \\
\hline \multicolumn{8}{|l|}{$10.00-11.00$} \\
\hline \multicolumn{8}{|l|}{$11.00-12.00$} \\
\hline \multicolumn{8}{|l|}{$12.00-13.00$} \\
\hline \multicolumn{8}{|l|}{$13.00-14.00$} \\
\hline \multicolumn{8}{|l|}{$14.00-15.00$} \\
\hline \multicolumn{8}{|l|}{$15.00-16.00$} \\
\hline \multicolumn{8}{|l|}{$16.00-17.00$} \\
\hline \multicolumn{8}{|l|}{ 17.00-18.00 } \\
\hline \multicolumn{8}{|l|}{ 18.00-19.00 } \\
\hline \multicolumn{8}{|l|}{ Nurse signature: } \\
\hline \multicolumn{8}{|l|}{$19.00-20.00$} \\
\hline \multicolumn{8}{|l|}{$20.00-21.00$} \\
\hline \multicolumn{8}{|l|}{$21.00-22.00$} \\
\hline \multicolumn{8}{|l|}{$22.00-23.00$} \\
\hline \multicolumn{8}{|l|}{$23.00-24.00$} \\
\hline \multicolumn{8}{|l|}{$0.00-1.00$} \\
\hline \multicolumn{8}{|l|}{$1.00-2.00$} \\
\hline \multicolumn{8}{|l|}{$2.00-3.00$} \\
\hline \multicolumn{8}{|l|}{$3.00-4.00$} \\
\hline \multicolumn{8}{|l|}{$4.00-5.00$} \\
\hline \multicolumn{8}{|l|}{$5.00-6.00$} \\
\hline \multicolumn{8}{|l|}{$6.00-7.00$} \\
\hline Nurse signature & & & & & & & \\
\hline
\end{tabular}

